\title{
Chitin and Chitosan Induce Migration of Bovine Polymorphonuclear Cells
}

Yasuyuki USAMI, Yoshiharu OKAMOTO*, Saburo MINAMI, Akira MATSUHASHI, Norichica H. KUMAZAWA ${ }^{1)}$, Shin-ichiro TANIOKA $^{3)}$, and Yoshihiro SHIGEMASA ${ }^{2)}$

Departments of Veterinary Surgery and ${ }^{1)}$ Veterinary Public Health, Faculty of Agriculture, ${ }^{2)}$ Department of Materials Science, Faculty of Engineering, Tottori University, 101 Minami 4-chome, and ${ }^{3)}$ Sunfive Co., Ltd., 133 Higashi 5-chome, Koyama-cho, Tottori 680, Japan (Received 30 November 1993/Accepted 18 February 1994)

ABSTRACT. Bovine polymorphonuclear cells (PMNs) were found to migrate to suspensions of finely granulated chitin and chitosan of an average size of $1 \mu \mathrm{m}$ at higher rates than to those of an average size of 30 and $50 \mu \mathrm{m}$, respectively, through a $5 \mu \mathrm{m}$ pore size polycarbonate filter in a Blind well chamber.-KEY wORDS: bovine polymorphonuclear cell, chitin and chitosan, migration.

Chitin, a polymer of $\mathrm{N}$-acetyl-D-glucosamine, is widely distributed as the skeletal material of crustaceans and insects, and as a component of cell walls of bacteria and fungi, while chitosan, a polymer of D-glucosamine, is composed of fungal cell wall [5] and easily obtained by deacetylation of chitin. Wound healing was reported to be accelerated by chitin and chitosan agents in recent studies by us $[2-4,6,8]$. However, little is known about the mechanism of the accelerated wound healing. In light microscopic evidence that polymorphonuclear cells (PMNs) densely accumulated around implanted chitin and chitosan agents in an early phase of wound repair in cows and dogs [4, 7], it was suggested that chitin and chitosan promote migratory activity of PMNs. In the present study, bovine PMNs were confirmed to migrate in vitro to suspensions of chitin and chitosan granules.

Animals: Three Holstein cows (3-7 years old) were used as donors of peripheral blood in the present study. They were in good health without any hematological or biochemical disorders.

Cell preparation: Five $\mathrm{m} l$ of peripheral blood was collected with a syringe containing heparin $(10$ units $/ \mathrm{m} l$ of blood) from a jugular vein, diluted with $10 \mathrm{~m} l$ Hank's balanced salt solution (HBSS), placed on $15 \mathrm{ml}$ of Ficoll-Conray solution (specific gravity of 1.085), and centrifugated at 2,500 rpm for $30 \mathrm{~min}$ at room temperature to obtain a PMN-rich cell suspension. The cell suspension was treated with $0.83 \%$ ammonium chloride $\left(\mathrm{NH}_{4} \mathrm{Cl}\right)$ to hemolyze erythrocytes, washed twice with HBSS, and then suspended in HBSS at a cell density of $2 \times 10^{5}$ per $\mathrm{m} l$.

Chitin and chitosan: Chitin (less than $30 \%$ deacetylated) and chitosan (more than $80 \%$ deacetylated) were supplid by Sunfive Co., Ltd. (Japan). Chitin and chitosan granules were prepared in the following sizes: $1 \mu \mathrm{m}$ (range from 0.2 to $3 \mu \mathrm{m}$ ) and $30 \mu \mathrm{m}$ (range from 0.4 to $192 \mu \mathrm{m}$ ), and $1 \mu \mathrm{m}$ (range from 0.2 to $3 \mu \mathrm{m}$ ) and $50 \mu \mathrm{m}$ (range from 6 to 203 $\mu \mathrm{m}$ ) on average, respectively, and were suspended in HBSS at a concentration of $1 \mathrm{mg}$ per $\mathrm{m} l$. Distributions of the sizes of these granules were measured with an SK Laser Micron Sizer 7000S (Seisin K. K., Japan).

Measurement of bovine PMNs migration: Migration of

\footnotetext{
* Correspondence to: OKamoto, Y., Department of Veterinary Surgery, Faculty of Agriculture, Tottori University, 101 Minami 4-chome, Koyama-cho, Tottori 680, Japan.
}

bovine PMNs through a $5 \mu \mathrm{m}$ pore-sized polycarbonate filter (Nucle Pore Co., Ltd., U.S.A.) was measured in Blind well chambers (Neuro Probe Co., Ltd., U.S.A.). Two hundred $\mu l$ chitin and chitosan suspensions or HBSS alone was placed into the lower chamber. A polycarbonate filter was placed between the lower chamber and the upper chamber. Two hundred $\mu l$ of the cell suspension was added to the upper chamber. The chambers were incubated at $37^{\circ} \mathrm{C}$ for $60 \mathrm{~min}$. The filters were then removed, air-dried, fixed in methanol, stained with Light-Giemsa solution and mounted on glass slides. The migrated cells which completely passed through the pores and attached to the lower surface of the filter were counted for 30 randomly selected oil immersion fields under a microscope at a magnification of 1,000 . The results were expressed as the number of bovine PMNs per $\mathrm{mm}^{2}$ filter surface.

Statistical analysis: Statistical analysis was performed by Student's $t$-test.

The purity and viability of bovine PMNs in the resulting cell suspensions were more than $90 \%$ and $95 \%$, respectively.

Numbers of bovine PMNs migrated to chitin and chitosan granules are shown in Table 1. Bovine PMNs migrated to chitin and chitosan particles of an average size of $1 \mu \mathrm{m}$ at higher rates than to those of an average size of 30 and $50 \mu \mathrm{m}$, respectively, through a $5 \mu \mathrm{m}$ pore size polycarbonate in the Blind well chamber $(\mathrm{p}<0.01)$. Bovine PMNs migrated to chitosan particles more than that to chitin particles of an average size of $1 \mu \mathrm{m}$ $(\mathrm{p}<0.01)$. On the other hand, bovine PMNs migrated to chitin particles of an average size of $50 \mu \mathrm{m}$ more than to chitosan particles of an average size of $30 \mu \mathrm{m}(\mathrm{p}<0.01)$. Bovine PMNs migrated to particles of all sizes more than HBSS alone $(\mathrm{p}<0.01)$.

Bovine PMNs were found to migrate to the chitin and chitosan suspensions in the Blind well chamber. This migration was remarkable in the more finely granulated chitin and chitosan suspensions. Bovine and canine PMNs were found to accumulate at subcutaneously implanted chitin and chitosan agents in recent studies by us [4, 7]. Intraperitoneal administration of chitin to mice was reported to increase the number of peritoneal exudate cells within $3 \mathrm{hr}$ [10]. Thus our evidence seems to be a good in vitro model of the enhanced cell accumulation at chitin and chitosan-administered regions at an early stage 
Table 1. Effect of chitin and chitosan on migration of bovine PMNs through a $5 \mu \mathrm{m}$ pore size polycarbonate filter at $37^{\circ} \mathrm{C}$ for $60 \mathrm{~min}$

\begin{tabular}{lccc}
\hline Sample $^{\mathrm{a})}$ & $\begin{array}{c}\text { Average size } \\
(\mu \mathrm{m})\end{array}$ & $\begin{array}{c}\text { Distribution } \\
(\mu \mathrm{m})\end{array}$ & $\begin{array}{c}\text { Migrated cells } \\
\text { per } \mathrm{mm}^{2} \text { filter surface }{ }^{\mathrm{b})}\end{array}$ \\
\hline Chitin & 1 & $0.2-3$ & $51 \pm 12^{\mathrm{A}}$ \\
1 & 30 & $0.4-192$ & $33 \pm 9^{\mathrm{B}}$ \\
2 & 1 & $0.2-3$ & $84 \pm 10^{\mathrm{C}}$ \\
Chitosan & 50 & $6-203$ & $6 \pm 2^{\mathrm{D}}$ \\
1 & - & - & $2 \pm 1^{\mathrm{E}}$ \\
2 & & - & \\
HBSS & & & \\
\hline
\end{tabular}

a) Each sample was used at a concentration of $1 \mathrm{mg} / \mathrm{ml}$.

b) Mean \pm SD.

A, B, C, D, E: Mean values with different superscripts are significantly different $(\mathrm{p}<0.01)$.

of wound healing in domestic animals.

The Blind well chamber technique is easy to use and is readily reproduced. From our preliminary study with $E$. coli YS-2, optimum conditions for a migration assay of bovine PMNs in a Blind well chamber were expected to be a $5 \mu \mathrm{m}$ pore-sized filter and an incubation time of $60 \mathrm{~min}$ at $37^{\circ} \mathrm{C}$. Under these conditions, bovine PMNs showed active migration to chitin and chitosan granules of an average size of $1 \mu \mathrm{m}$ and poor migration to those of an average size exceeding $30 \mu \mathrm{m}$. Chitin and chitosan, water-unsoluble polysaccharides, have not known to induce the bioactivity in vitro. As to the mechanism of bovine PMNs migration to chitin and chitosan suspensions, it is thought that finely granulated chitin and chitosan themselves might directly or indirectly enhance the migratory activity of bovine PMNs. It has been reported that lipopolysaccharide (LPS) and zymosan could activate PMNs $[1,9,11]$. Glucan, the major polysaccharide of zymosan, was shown to enhance the generation of reactive oxygen species from PMNs [12]. A water-soluble oligosaccharide, $\mathrm{N}$-acetylchitohexaose, was shown to attract mouse PMNs [10]. Our results indicate that finely granulated chitin and chitosan could also enhance bovine PMNs activity.

Our results should be important in assessing the acceleration of wound healing with chitin agents in domestic animals.
REFERENCES

1. Creamer, H. R., Hunter, N., Bullock, W. W., and Gabler, W. L.1991. Inflammation 15: 201-211.

2. Minami, S., Okamoto, Y., Umemura, T., Sashiwa, H., Saimoto, H., Shigemasa, Y., and Matsuhasi, A. 1991. Jpn. J. Equi. Sci. 2: 65-70.

3. Minami, S., Okamoto, Y., Matsuhashi, A., Sashiwa, H., Saimoto, H., Shigemasa, Y., Tanigawa, T., Tanaka, Y., and Tokura, S.1992. pp. 61-69. In: Advances in Chitin and Chitosan (Brine, C. J., Sandford, P. A., and Zikakis, J. P. eds.), Elsevier Applied Sci., New York.

4. Minami, S., Okamoto, Y., Tanioka, S., Sashiwa, H., Saimoto, H., Matsuhashi, A., and Shigemasa, Y. 1992. pp. 142-152. In: Carbohydrates and Carbohydrate Polymers (Yalpani, M. ed.), ATL Press, Mount Prospect.

5. Muzzarelli, R. A. A. 1977. Chitin. pp. 5-8. Pergamon Press, Oxford.

6. Okamoto, Y., Minami, S., Matsuhashi, A., Sashiwa, H., Saimoto, H., Shigemasa, Y., Tanigawa, T., Tanaka, Y., and Tokura, S. 1992. pp. 70-78. In: Advances in Chitin and Chitosan (Brine, C. J., Sandford, P. A., and Zikakis, J. P. eds.), Elsevier Applied Sci., New York.

7. Okamoto, Y., Minami, S., Matsuhashi, A., Sashiwa, H., Saimoto, H., Shigemasa, Y., Tanigawa, T., Tanaka, Y., and Tokura, S. 1993a. J. Vet. Med. Sci. 55: 739-742.

8. Okamoto, Y., Minami, S., Matsuhashi, A., Sashiwa, H., Saimoto, H., Shigemasa, Y., Tanigawa, T., Tanaka, Y., and Tokura, S. 1993b. J. Vet. Med. Sci. 55: 743-747.

9. Olson, D. P. 1990. Am. J. Vet. Res. 51: 973-972.

10. Suzuki, K., Tokoro, A., Okawa, Y., Suzuki, S., and Suzuki, M. 1986. Microbiol. Immunol. 30: 777-787.

11. Thomsen, M. K. and Jensen, A. L. 1991. Vet. Immunol. Immunopathol. 29: 197-211.

12. Williams, J. D., Topley, N., Alobaidi, M., and Harber, M. J. 1986. Immunology 58: 117-124. 